\title{
Review of the Use of Fire Dynamics Theory in Fire Service Activities
}

\author{
Nils Johansson* (D), Division of Fire Safety Engineering, Lund University, P.O. \\ Box 118, 22100 Lund, Sweden \\ Stefan Svensson, Swedish Civil Contingencies Agency, Revinge, Sweden
}

Received: 9 February 2018/Accepted: 8 September 2018

\begin{abstract}
The work of the fire service has changed during the last decades from being essentially operational to include a larger variety of activities to increase fire safety in society. Also, the theoretical understanding of fire development, fire dynamics in buildings and fire safety engineering have improved. There are several good examples of areas were fire dynamics theories have supported and improved the fire service activities associated with building fire safety during the last decades. Despite such examples the quality of knowledge transfer between theory and research, and the more practical arena, such as fire service activities is sometimes questionable. This paper includes a systematic literature review and an interview study that is used to discuss how fire dynamics is used to support fire service activities today and where the use of fire dynamics theory could or should be increased in the future. It is found in the paper that fire dynamics theories are currently used more in the preventative and investigative areas than in the operational area of fire service activities. The primary reasons for this is that the timeframe is much shorter in the latter and that there are established procedures and tactics that work well for the common operational situations. However, there is a potential to use fire dynamics theories more in the operational area when it comes to events that occurs less frequent and with a longer duration than for example the normal compartment fire. In general, there is room for improvement of the use of fire dynamics in the fire service and a way forward could be a stronger link between theory and practice in education and training.
\end{abstract}

Keywords: Fire service, Fire dynamics, Fire prevention, Fire investigations, Fire safety engineering

\section{Background}

The work of the fire service has changed, from being essentially operational and working with fire inspections [1]; to include education, investigations and collaboration with other actors and they have taken a more active role in safety in society $[2,3]$. At the same time, society has become more complex, including building materials as well as infrastructure. This has increased the need for the fire service to have an in-depth knowledge in fire safety engineering and fire dynamics. As an example The London Fire Brigade established a Fire Engineering Group in the early 1990 s as a response to the widening gap of knowledge in fire safety engineer-

\footnotetext{
* Correspondence should be addressed to: Nils Johansson, E-mail: nils.johansson@brand.lth.se
} 
ing between fire officers and the private sector of fire consultants [4]. Another example is the Fire Engineering Unit that has been developed in the Greater Manchester Fire Rescue and Services [5]. Similar trends can be seen outside the UK, such as in Sweden when the fire safety engineering program was established at Lund University in 1986 [6]. It should be noted that a bachelor degree (or higher) is one of two different requirements for senior fire officers and fire chiefs in Sweden [7]. Jenkins [4] describes the work the London Fire Brigade comes in contact with as including fire-engineered building proposals and the importance of having an appreciation of the relevant fire dynamics including possible fire loads, fire growth rates and smoke filling calculations in the fire engineering approvals process. This is important when there is a disagreement between the parties involved because, as Jenkins [4] writes, being able to quantify the problem by putting numbers on factors that are contested rather than relaying on a gut feeling helps resolving issues and find consensus. Wang et al. [5] confirms that an understanding of the scientific and engineering principles of fire engineering solutions is needed in order to review the design concepts and assumptions and to judge the correctness of a design solution. Also, Wang et al. [5] discusses the role of the fire authority from the fire consultants' perspective. Wang et al. argues that the fire authority can only raise issues when they have competence to do so, and that is according to Wang et al. not always the case.

When it comes to work on the fire ground the fire service obviously needs knowledge in fire dynamics, and this need might have increased during the last decades. Madrzykowski [8] points out that there have been changes in the room fire environment that the fire service faces, this is due to e.g. new materials in furnishings, more energy efficient buildings and new construction methods and building designs. Madrzykowski argues that the synergy effect of such changes on the fire dynamics is not widely known in the fire service, resulting in that firefighters and fire officers needs to improve their knowledge about fire dynamics theory.

The increased possibility for fire services to collect and analyse data before, during and after a fire have highlighted the opportunity for so-called smart firefighting [9]. Smart firefighting includes a broad spectrum of activities; however, the fundamental principle is to use data from different kinds of sensors to analyse and evaluate fire incidents. This can be data from stationary or mobile sensors and it can be a real-time analysis of an on-going event or an analysis pre -or post-incident. Even though smart firefighting includes tools to support decision making it is important for the individual to be able to interpret the information and understand the principles of how the analysis tools are working. Smart fire fighting is not so widely spread at present, however, the ability to understand the underlying fire dynamics in advanced computer models like e.g. computational fluid dynamics (CFD) models is something that the fire service as a regulator body in the building process is expected to do today in many countries around the world.

There are a few examples of educational literature on fire dynamics aimed at fire service personnel [10-13]. Though, the fire service is discussed more often in specific trade magazines. The discussion in such media is, by purpose, not as deep or extensive as that in educational material or in peer-reviewed articles. 


\subsection{Examples of How Fire Dynamics Theory can be Used in the Fire} Service

There are several examples of areas were fire dynamics theories and experiments can support and improve firefighting activities. A brief description of three such areas are given in this section in order to previous discussion into a context.

The first example is positive pressure ventilation (PPV), which is regarded as one of the most advantageous fire fighting tools in small and medium-sized buildings [12]. Since the first demonstrations of PPV tactics in the 1970ties [14] the use of PPV has been studied extensively both experimentally and theoretically, and recommendations and practical guides on the use of PPV to mitigate or control the spread of fire and smoke in buildings have been provided $[15,16]$. These recommendations and practical guides based in science and knowledge has been transferred to the fire service community, through educational material and training opportunities. As an example, a term called the airflow factor can be used to determine the adequate size of an outlet opening for efficient positive pressure ventilation [16]. The airflow factor relates the outlet area in a building $\left(A_{T}\right)$ to the inlet opening $\left(A_{F}\right)$ see Eq. 1, and it describes the effectiveness of the airflow. The airflow effectiveness increases as the $A_{T} / A_{F}$ ratio increases, when the ratio is above 2 the effectiveness will be more than $90 \%$, see Fig. 1 .

$$
\text { Airflow factor }=\frac{A_{F} / A_{T}}{\sqrt{1+\left(A_{F} / A_{T}\right)^{2}}}
$$

The second example is the relation between firefighting water and fire intensity (heat release rates) see Fig. 2. The maximum heat release rate in a ventilation-controlled compartment fire $\left(\dot{Q}_{\max }\right)$ depends on the size of the openings and it can be calculated with Eq. $2[17,18]$, where $A_{o}$ is the total area of the openings and $H_{o}$ is the weighted height of the openings. The water flow rates needed to extinguish a fire in a reasonable time vary between occupancy type and compartment size; however, there are some rules of thumb that can be applied. Barnett [19] estimates

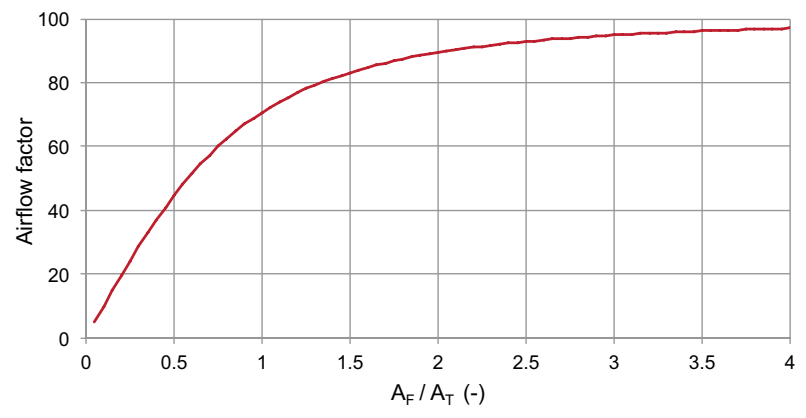

Figure 1. Relationship between the $A_{T} / A_{F}$ ratio and the airflow factor. 


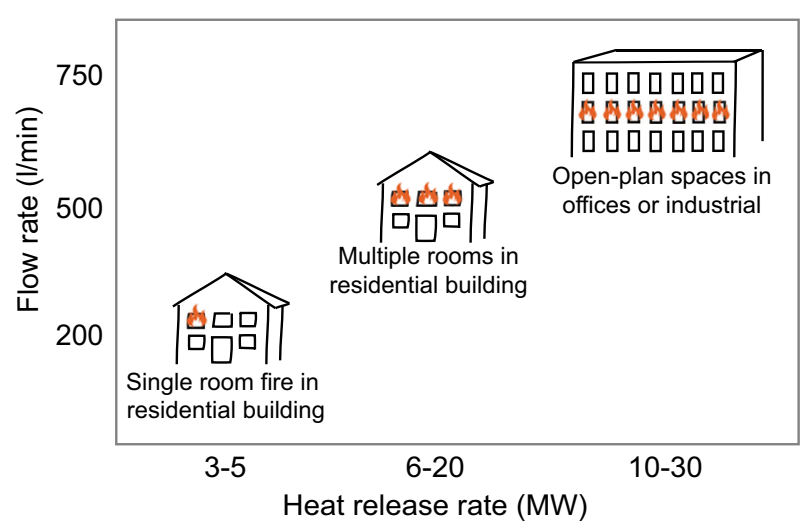

\section{Figure 2. Schematic relationship between heat release rate and the needed firefighting water flow to extinguish fire.}

the firefighting water flow to $0.38 \mathrm{1} / \mathrm{s}$ and $\mathrm{MW}$, which is similar to the estimate of $0.41 \mathrm{l} / \mathrm{s}$ and MW by Grimwood [12]. This means, as an example, that a water flow rate of about $1.7 \mathrm{l} / \mathrm{s}(102 \mathrm{l} / \mathrm{min})$ would be required to extinguish a fire in a single room with an open $1 \mathrm{~m}$ by $2 \mathrm{~m}$ door, which in means that a single hose line that delivers $300 \mathrm{l} / \mathrm{min}$ would be adequate to put out this fire.

$$
\dot{Q}_{\max }=1.518 A_{o} \sqrt{H_{o}}
$$

The third and final example relates to fire spread through thermal radiation. Simple estimate calculations of the possible thermal radiation from a building fire can be done in order to asses the possibility of fire spread and if any action should be taken to protect neighbouring buildings. The thermal radiation from a flame in a window or other opening in a burning building to another adjacent building can be estimated with Eq. 3 . The flame with the temperature, $T_{f}$, is approximated to a circle with a diameter, $D$, and it is located at a distance, $R$, from the adjacent building. If the height of flame extending from an opening is used as $D$, the estimate will most likely be conservative. There are more advanced methods to calculate thermal radiation [17]; still, Eq. 3 provides a simple method that can be done by hand.

$$
\dot{q}^{\prime \prime}=\varepsilon \sigma T_{f}^{4} \frac{D^{2}}{4 R^{2}+D^{2}}
$$

where $\varepsilon$ is the emissivity and $\sigma$ is the Stefan-Boltzmann constant, $5.67 \times 10^{-}$ ${ }^{11} \mathrm{~kW} / \mathrm{m}^{2} \mathrm{~K}^{4}$. Assuming an emissivity of 1 and a flame temperature of $1200 \mathrm{~K}$ results in the following form of Eq. 3, where $\dot{q}^{\prime \prime}$ is given in $\mathrm{kW} / \mathrm{m}^{2}$. 


$$
\dot{q}^{\prime \prime}=120 \cdot \frac{D^{2}}{4 R^{2}+D^{2}}
$$

The critical radiant heat flux on wood is $12 \mathrm{~kW} / \mathrm{m}^{2}$ when a pilot flame [18] (i.e. spark or ember) is present. As an example, this means that a flame height of approximately $2.7 \mathrm{~m}$ can ignite a wood façade $4 \mathrm{~m}$ away.

Despite examples like the ones above, this type of research based knowledge is only occasionally used or transferred to a more practical arena like fire service operations. This paper reviews how fire dynamics theory is used to support different kinds of activities within the fire service and identifies areas within the field where fire dynamics could and maybe should be used more.

\section{Objective}

The objective of this paper is to systematically review and discuss how fire dynamics theory is used or can be used to: improve, support or evaluate fire service activities associated with building fire safety. The term fire service activities include the preventative, operational and investigative areas of the work done by the fire service. An important part of the paper is to identify areas within the field of fire service operations where fire dynamics theory is or could be used. The primary target group of this paper are fire officers that have an understanding of fire dynamics theory or even a university degree in fire safety engineering. Even so, the paper is also relevant for firefighters or other people working within or with the fire service.

\section{Method}

This is an exploratory study where two different methods are used. Firstly, relevant research that is searchable in scientific databases is reviewed systematically in a literature review. Secondly, an interview study is conducted amongst fire officers within the Swedish fire service. The results from these two used methods are discussed in conjunction and conclusions are drawn.

\subsection{Description of Literature Review}

A systematic literature review was conducted in order to summarise the relevant research literature with regard to how fire dynamics theory is used in fire service operations. More specifically the intention of literature review was to find publications where fire dynamics theory was used to improve, support or evaluate fire service activities. The following four steps were applied when the review was performed:

1. Specification of keywords and databases

2. Screen and selection of publications based on abstract

3. Screen and selection of publications based on entire publication 
4. Review of selected publications

The outcome of the different steps and result of the review is presented in Sect. 4.

\subsection{Description of Interview Study}

An interview study with people working in the fire service or in close relation to the fire service in Sweden was conducted as a complement to the literature review. The purpose of the interview study was to get insight into the following three areas:

- Present use of fire dynamics theory in fire service activities

- Potential and need of using fire dynamics theory in fire service activities

- Present status in the education of fire dynamics theory in relation to fire service activities

In order to get good input the interviewees needed to have a good understanding of fire development and fire dynamics theory. The interviewees were therefore selected based on their competence and knowledge in this area, which means that their views are most likely not representative for the average fire officer.

\section{Liferature Review}

The outcome of the four steps in the systematic literature review as specified in Sect. 3.1 is presented in this section.

\subsection{Specification of Keywords and Databases}

Two databases were selected for the literature review, Web of Science [20] and Scopus [21]. Web of Science includes a range of different types of publications, like: journal papers, websites and conference proceedings. Scopus claims to be the largest abstract and citation database of peer-reviewed literature, scientific journals, books and conference proceedings [21]. Scopus has a larger coverage ( $>20,000$ journals) compared to Web of Science ( $>12,000$ journals). However, Web of Science is said to have a greater time period of coverage than Scopus [22]. By using these two databases the scientific literature is consider to be covered satisfyingly.

The keywords were chosen to in order to find published material that discussed both fire dynamics and fire service activities associated with building fire safety. In total 20 different keyword combinations were used. These are presented in Table 1 .

The searches were conducted in the "article title, abstract and keyword" field in Scopus and with the "Topic" function in Web of Science. The "Topic" function in Web of Science includes searches in the title, abstract, author keywords and keywords plus fields. 


\section{Table 1}

Combinations of Keywords and Number of Hits in the Two Databases

\begin{tabular}{lcr}
\hline & \multicolumn{2}{c}{ Articles found in databases } \\
\cline { 2 - 3 } Keywords & Web of Science & Scopus \\
\hline Fire dynamics + fire service & 5 & 11 \\
Fire dynamics + rescue service & 0 & 2 \\
Fire dynamics + fire fighting & 13 & 51 \\
Fire dynamics + fire brigade & 1 & 2 \\
Fire dynamics + first responder & 0 & 1 \\
Fire modelling + fire service & 0 & 2 \\
Fire modelling + rescue service & 0 & 3 \\
Fire modelling + fire fighting & 5 & 23 \\
Fire modelling + fire brigade & 1 & 3 \\
Fire modelling + first responder & 0 & 0 \\
Fire engineer* + fire service & 4 & 54 \\
Fire engineer* + rescue service & 3 & 14 \\
Fire engineer* + fire fighting & 8 & 73 \\
Fire engineer* + fire brigade & 3 & 26 \\
Fire engineer* + first responder & 0 & 0 \\
Fire safety engineer* + fire service & 4 & 3 \\
Fire safety engineer* + rescue service & 0 & 23 \\
Fire safety engineer* + fire fighting & 4 & 9 \\
Fire safety engineer* + fire brigade & 3 & 0 \\
Fire safety engineer* + first responder & 0 & 314 \\
Total & 54 & \\
Total both databases (unique) & $368(168)$ & \\
\hline & &
\end{tabular}

\footnotetext{
a"Modelling" is usually spelt with a single- $\mathrm{L}$ in the United States while double- $\mathrm{L}$ is used in most other English speaking countries. The double-L spelling was used in the search. Even so, it has been investigated if the alternative spelling affects the total number of unique articles found, and that is not the case
}

The search was performed in August and September 2017 and a total of 168 unique hits were found (see Table 1).

\subsection{Screen and Selection of Publications Based on Abstract}

The abstract or introduction (depending on the layout of the publication) of the 168 unique publications was read in order to distinguish if it included an application of fire dynamics theory in any type of fire service activities (including operations as well as preventive and investigative work). This resulted in a reduced list of 55 publications. The major part of the disregarded publications dealt in some way with fire dynamics but not in any relevant relation to the fire service.

\subsection{Screen and Selection of Publications Based on Entire Publication}

The remaining 55 publications were read and it could be determined definitely for each publication if it included an application of fire dynamics theory in any type of fire service actions. Several papers were excluded after the read-through and the final list included 20 publications (see Table 2). The major part of the publications 


\section{Table 2}

The Final List of Publications Used in the Review

\begin{tabular}{|c|c|c|c|c|}
\hline Title & Source & $\begin{array}{l}\text { Type of } \\
\text { Sorce }\end{array}$ & Year & $\begin{array}{l}\text { Ref. } \\
\text { no. }\end{array}$ \\
\hline $\begin{array}{l}\text { Firefighters risk during sanitation of chemical acci- } \\
\text { dents }\end{array}$ & $\begin{array}{l}\text { Pozarni Ochrana } \\
2010\end{array}$ & $\begin{array}{l}\text { Conf. } \\
\text { paper }\end{array}$ & 2010 & [23] \\
\hline $\begin{array}{l}\text { Detailed analysis of a smouldering fire scenario at } \\
\text { the murder scene experimental and numerical } \\
\text { investigations }\end{array}$ & Fire and Materials & $\begin{array}{l}\text { Peer } \\
\text { reviewed } \\
\text { journal }\end{array}$ & 2014 & {$[24]$} \\
\hline $\begin{array}{l}\text { Analysis of One and TwoStory Single Family Home } \\
\text { Fire Dynamics and the Impact of Firefighter Hor- } \\
\text { izontal Ventilation }\end{array}$ & Fire Technology & $\begin{array}{l}\text { Peer } \\
\text { reviewed } \\
\text { journal }\end{array}$ & 2013 & {$[25]$} \\
\hline $\begin{array}{l}\text { Analysis of Changing Residential Fire Dynamics } \\
\text { and Its Implications on Firefighter Operational } \\
\text { Timeframes }\end{array}$ & Fire Technology & $\begin{array}{l}\text { Peer } \\
\text { reviewed } \\
\text { journal }\end{array}$ & 2012 & {$[26]$} \\
\hline $\begin{array}{l}\text { The County/Metro research into firefighting suppres- } \\
\text { sive capacity and the impact on building fire dam- } \\
\text { age at }>5000 \text { UK building fires }\end{array}$ & Fire Safety Journal & $\begin{array}{l}\text { Peer } \\
\text { reviewed } \\
\text { journal }\end{array}$ & 2015 & {$[27]$} \\
\hline $\begin{array}{l}\text { A performance based approach to defining and cal- } \\
\text { culating adequate firefighting water using s.8.5 of } \\
\text { the design guide BS PD 7974:5:2014 }\end{array}$ & Fire Safety Journal & $\begin{array}{l}\text { Peer } \\
\text { reviewed } \\
\text { journal }\end{array}$ & 2015 & [28] \\
\hline $\begin{array}{l}\text { A water requirements estimation model for fire sup- } \\
\text { pression: A study based on integrated uncertainty } \\
\text { analysis }\end{array}$ & Fire Technology & $\begin{array}{l}\text { Peer } \\
\text { reviewed } \\
\text { journal }\end{array}$ & 2005 & [29] \\
\hline CFD - convincing the regulator & $\begin{array}{l}\text { Fire Risk Manag- } \\
\text { ment }\end{array}$ & Magazine & 2008 & {$[30]$} \\
\hline $\begin{array}{l}\text { Forecasting fire dynamics using inverse computa- } \\
\text { tional fluid dynamics and tangent linearisation }\end{array}$ & $\begin{array}{l}\text { Advances in Engi- } \\
\text { neering Software }\end{array}$ & $\begin{array}{l}\text { Peer } \\
\text { reviewed } \\
\text { journal }\end{array}$ & 2011 & [31] \\
\hline $\begin{array}{l}\text { Assessment of development time of a smouldering } \\
\text { fire at a crime scene experimental and numerical } \\
\text { investigations }\end{array}$ & Fire and Materials & $\begin{array}{l}\text { Conf. } \\
\text { paper }\end{array}$ & 2011 & [32] \\
\hline Dynamic investigations & $\begin{array}{l}\text { Fire Prevention \& } \\
\text { Fire Engineers } \\
\text { Journal }\end{array}$ & Magazine & 2005 & [33] \\
\hline $\begin{array}{l}\text { Towards agent-based GRID-enabled and sensor-dri- } \\
\text { ven fire dynamics simulation harnessed over Blue- } \\
\text { tooth and Wi-Fi devices }\end{array}$ & $\begin{array}{l}\text { Proceedings of the } \\
\text { IDETC/CIE }\end{array}$ & $\begin{array}{l}\text { Conf. } \\
\text { paper }\end{array}$ & 2005 & [34] \\
\hline High Profile & $\begin{array}{l}\text { Fire Risk Manag- } \\
\text { ment }\end{array}$ & Magazine & 2011 & {$[35]$} \\
\hline The firefighter as regulator & Fire and Explosions & $\begin{array}{l}\text { Conf. } \\
\text { paper }\end{array}$ & 1999 & [36] \\
\hline $\begin{array}{l}\text { The Use of CFD Calculations to Evaluate } \\
\text { FireFighting Tactics in a Possible Backdraft Situa- } \\
\text { tion }\end{array}$ & Fire Technology & $\begin{array}{l}\text { Peer } \\
\text { reviewed } \\
\text { journal }\end{array}$ & 2009 & {$[37]$} \\
\hline Sensor Assisted Fire Fighting & Fire Technology & $\begin{array}{l}\text { Peer } \\
\text { reviewed } \\
\text { journal }\end{array}$ & 2008 & {$[38]$} \\
\hline $\begin{array}{l}\text { Improvement of Positive Pressure Ventilation by } \\
\text { optimizing stairwell door opening area }\end{array}$ & Fire Safety Journal & $\begin{array}{l}\text { Peer } \\
\text { reviewed } \\
\text { journal }\end{array}$ & 2017 & [39] \\
\hline
\end{tabular}




\begin{tabular}{|c|c|c|c|c|}
\hline Title & Source & $\begin{array}{l}\text { Type of } \\
\text { Sorce }\end{array}$ & Year & $\begin{array}{l}\text { Ref. } \\
\text { no. }\end{array}$ \\
\hline $\begin{array}{l}\text { Positive Pressure Ventilation for fighting wind- } \\
\text { driven high-rise fires: Simulation-based analy- } \\
\text { sis and optimization }\end{array}$ & Fire Safety Journal & $\begin{array}{l}\text { Peer } \\
\text { reviewed } \\
\text { journal }\end{array}$ & 2017 & [40] \\
\hline $\begin{array}{l}\text { Simulation of bus fires in the hsuehshan tunnel, } \\
\text { Taiwan, using the software fire dynamics sim- } \\
\text { ulator }\end{array}$ & $\begin{array}{l}\text { Journal of Applied } \\
\text { Fire Science }\end{array}$ & $\begin{array}{l}\text { Peer } \\
\text { reviewed } \\
\text { journal }\end{array}$ & 2013 & [41] \\
\hline $\begin{array}{l}\text { Froude Modelling of Fire Phenomena: Observa- } \\
\text { tion of Fire-induced Smoke Movement in } \\
\text { Basement Structure for Firefighting Purpose }\end{array}$ & $\begin{array}{l}\text { Engineering Physics } \\
\text { International Confer- } \\
\text { ence }\end{array}$ & $\begin{array}{l}\text { Peer } \\
\text { reviewed } \\
\text { conf. paper }\end{array}$ & 2016 & {$[42]$} \\
\hline
\end{tabular}

The order of the publications is based on the sequence that they were read

ignored at this stage was, as in the previous stage, not related to fire service activities. Furthermore, publications older than 20 years were not included because the intention of this work is to give a view of the current situation.

The type of publication source in Table 2 varies; however, the majority of the sources are peer reviewed scientific journals, which ensures a certain quality of the content. A couple of magazine articles are also included in the list; these have not undergone the same quality check although can provide another, sometimes more practical, perspective which can be valuable.

\subsection{Review of Selected Publications}

The review of the selected papers is done from the preventative, operational and investigative perspectives at the fire service.

4.4.1. Preventative The preventive work that is referred to here primarily includes the role of the fire service in the building design process and in fire inspections. When it comes to this type of preventative work and the use of fire dynamics theory's there are just a few examples found in the review.

Taylor [30] presents and discusses the assessments process and the regulators expectations on CFD submissions to the London Fire Brigade. Taylor writes that many consultants want to discuss their models and input values with the fire service in order to find a common ground. The regulator needs to have an understanding if probable worst-case scenarios are used and if the model used can represent them. Furthermore, the regulator needs to comprehend if the relevant results from the model is studied in the design proposal and that the designer acknowledges the limitations of the model used.

Streeter [36] raises the benefits and issues with fire officers that provide advice on fire safety matters. The practical experience of fighting fires for several years' results in a great know-how on how fires develops and smoke moves in a building. At the same time experience can differ between different fire officers, which 
may be reflected in the advice they give. Even so, Streeter [36] writes that the regulator has the duty to evaluate and questions the assumptions and modelling until confident that the system is reasonably safe.

4.4.2. Operational Several of the publications reviewed are related to planning or improving operational fire service procedures. Kerber [25] conducted a large series of full-scale experimental tests on fire service ventilation practices in modern family homes. Kerber studied how the position of the fan (low-high, near-remote) and ventilation openings influenced the fire dynamics in the building. The large amounts of data provided by Kerber have resulted in educational material and guidance to the fire service how to use of ventilation as a firefighting tactic [43].

Panindre et al. have in two different publications [39, 40] used the CFD model FDS to study different PPV tactics in fire service operations. In one of the publications Panindre et al. [39] looked at the effectiveness of PPV performance when a device called Door Open Area Reducer (DOAR) is applied to the inlet opening, simulations with and without DOAR were performed and it was seen that a proper deployment of DOAR significantly increased the pressure at all levels in a seven story high stairwell. The study also gives advice on how to place the fan and DOAR in relation to the opening. In another study Panindre et al. [40] looked at PPV and wind-driven fires with FDS. Simulations were carried out on a $20 \mathrm{~m}$ high apartment building and the fire was placed in an apartment on the fifth floor. Different wind speeds entering through a failed window in the apartment on fire were considered in the simulations as well as the possibility to use multiple PPV fans. The researchers demonstrate that PPV effectively reduces the temperature and that wind covering devices (in doors or windows) and multiple fans significantly improve the pressure levels in wind driven fires. Panindre et al. [40] states that simulation-based tools serve a great purpose in this type of analysis because large-scale experimental burns are costly and hard to duplicate.

Other areas where FDS have been applied include analysing environment that fire fighters will be subjected to in tunnel fires [23, 41] and firefighting tactics in ventilation controlled fires and possible backdraft situations [37]. The latter study results in some practical tactical guidance that is dependent on if people are left in the building or not.

In another publication Kerber [26] presents an experimental study where the change in residential fire environment over the past decades and its influence on firefighting is analysed. Kerber points out that: larger homes, open geometries, increased fuel load and new building materials can result in faster fire propagation. The experimental study shows that a modern living room can reach flashover within $5 \mathrm{~min}$ while it took in the order of $30 \mathrm{~min}$ for a legacy living room. This means that there is a big difference in the possibility for the fire service to intervene and as Kerber [26] states, there has been a change in the fire environment and it influences firefighting tactics.

The fire environment is something that Arini et al. [42] also studied. Arini et al. conducted small-scale fire tests and CFD simulations of basement fires and concluded that care must be taken when the firefighters tries to accesses the fire in the 
basement because smoke can fill up the access route which results in significant decrease in the visibility.

A couple of the publications reviewed deal with water usage and suppressive capacity [27-29] similar to the second example given in Sect. 1.1. Chang and Huang [29] presents a theoretical model to estimate the amount of water needed for suppression and it is evaluated with data from 100 fires that occurred in Taiwan. The authors consider the computed and observed values to be reasonably close if the fire suppression time was set to $20 \mathrm{~min}$. There were a lot of uncertainty in the empirical data; however, this type of model can potentially be used to make an initial assessment on the firefighting water volume required to supress a fire.

Grimwood and Sanderson [27] looked at the suppressive capacity in more than 5000 building fires. The fires were located in a county and a metro area and comparisons are made in the study between these two areas and several different aspects were analysed, like equipment and staffing and the relation between deployed firefighting flow rates and area of fire damage. Furthermore, Grimwood and Sanderson looked into a range of existing methods to estimate the amount of water needed for suppression. In another publication, Grimwood and Sanderson [28] raises the problem that several major high-rise fires have occurred in the UK where it was not possible to get the adequate water from the risers in the building and provides data that may be used to quantify the suppressive capability of a hose line or firefighting team in a large open plan floor fire.

Grimwood [35] discusses modern buildings and that these buildings with open floor plans, increase window area and with greater fire loads leading to more intense fires. Furthermore, Grimwood gives examples on high-rise fires in the UK with extensive fire spread both internally and externally, where the fire service intervention was insufficient to satisfyingly supress the fire. This in all makes Grimwood argue for the need of sprinkler systems to support in fire service operations in certain buildings.

Fire-forecasting and sensor assisted firefighting is an area that also appears in the reviewed publications $[31,34,38]$. Fire dynamics models can be used to forecast the fire development based on data from sensors, the model calculations are continuously updated with new data from the sensors, which means that changes in the environment (e.g. a window breakage) can be accounted for. When output data, like temperature measurements, are used to estimate model parameters it is called inverse modelling. Michopoulos et al. [34] present a technical paper on an infrastructure technology capable of providing decision support based on data from handheld sensors. The fundamental idea is that firefighters could get decision support based on the current situation and simulations.

Cowlard et al. [38] provides descriptions of some studies conducted to determine the limitations of existing fire models and sensor technologies that can be used for fire forecasting for the fire service. Cowlard et al. argues that current sensors and models are not capable of providing the information required by the fire service in order to use fire forecasting. The potential is great and it can provide much valuable information, a risk is however that sensor data can result in an information-overload. The way forward, according to the authors, is to use a 
combination of complex calculations, simple sub models and optimization of parameters using sensor data.

Jahn et al. [31] build on the work of Cowlard et al. and present a framework and proposes a mathematical methodology for forecasting of fire growth. Jahn et al. applies the methodology for a couple of cases and uses FDS as fire model. It is concluded that FDS is, at the time of the analysis, neither fast nor accurate enough to provide valid forecasts. Even so, Jahn et al. believes that the paper is a fundamental step towards the development of a forecast technology that can assist the fire service response.

4.4.3. Investigative Two publications presented by Hofmann et al. [24, 32] refer to extensive investigation of a specific fire event. Hofmann et al. used FDS to reproduce the event in order to investigate how the fire most likely started and developed. Information from the scene and from eyewitnesses as well as both experimental tests and simulations were used to build a timeline of events.

Finally, Berry [33] reports from a seminar about fire investigations where it was emphasised that understanding fire dynamics is important for fire investigators and fire safety engineers. It was also stressed that there is seldom useful data collected from fire investigations, because there historically the interest has been in fire cause and reasons for fire spread and not in the effectiveness of fire design, installations and management of fire safety systems.

\section{Inferview Słudy}

The interview study is conducted as a complement to the literature review in order to get an idea of how fire dynamics theory is used today in the fire service and if there is a need and potential for extended use.

\subsection{Description of Interviews and Interviewees}

A total of 11 interviews with 14 interviewees have been performed. Nine of the interviews were performed with a single interviewee, one with two interviewees and one with three interviewees. The total time for the interviews was approximately $16 \mathrm{~h}$. The interviews were recorded and notes were taken. Each interview was summarised in detail by the interviewer (i.e. first author) and the summary was sent to the interviewee for review and approval.

All of the interviewees except one had a degree in fire safety engineering. These people had an average work experience in the field of 14 years. The person with no degree in fire safety engineering had more than 15 years of experience as firefighter and fire officer (Table 3).

All interviews were performed in Swedish and the interviews were open, meaning that it was allowed for the interview to talk rather freely on the subject. Even so, an interview template was followed in each of the interviews (see appendix). 


\section{Table 3}

Information About the Inferviews and Interviews

\begin{tabular}{llclc}
\hline No. & Type of organisation & No. of interviewees & Type of interview & Time elapsed (min) \\
\hline 1 & Fire Service & 2 & In person & 89 \\
2 & Fire Service & 1 & In person & 70 \\
3 & Fire Service & 1 & In person & 73 \\
4 & Government agency & 1 & In person & 90 \\
5 & University & 1 & In person & 100 \\
6 & Fire Service & 3 & In person & 97 \\
7 & Government agency & 1 & Telephone & 77 \\
8 & Private company & 1 & Telephone & 96 \\
9 & Fire Service & 1 & Telephone & 46 \\
10 & Fire Service & 1 & Telephone & 69 \\
11 & Fire Service & 1 & Telephone & 79 \\
\hline
\end{tabular}

\subsection{Results from Interviews}

The questions in the interviews can be sorted in the three areas mentioned in Sect. 3.2, and the results in each area are divided into the three categories of fire service activities associated with building fire safety that were used in Sect. 4 namely: preventative, operational and investigative.

\subsubsection{Present Use of Fire Dynamics Theory in Fire Service Activities A rather} consistent picture emerges from the interviews in regard to how fire dynamics is used at the fire services. According to the interviewees assessments based on fire dynamics theory are, in general, used to some extent in the fire service. The theoretical background constitutes a fundament that is further built upon with the experience acquired whilst working in the fire service. However, fire dynamics theory is seldom or never used in any quantitative manner. Reflections with regard to fire dynamics are more frequently done qualitatively and to a higher degree based on practical experience.

Within the preventive area, remarks on building fire safety during an inspection are often motivated with references to the prescriptive requirements in the building code. However, according to several of the interviewees, it can also be done verbally with the help of a reasoning based on fire dynamics theory. A few interviewees gave examples of when calculations have been performed to support some statement; though, this seems to be very unusual. In such a case there is often a gap in knowledge about fire dynamics theory between the fire inspector and the building owner or operator, because the latter has in general very limited knowledge in fire dynamics. However, in the building design stage and especially in performance based design it can, according to some of the interviewees, be the other way around. In performance based design the fire service needs to know fire dynamics theory to interpret and question input data and results from calculations, and the person on the other side of the table, the fire consultant, might work daily with building design questions that the fire service encounters only on 
a yearly basis. In such a situation the fire service might not be as up to date as the consultants when it comes to fire dynamics and modelling.

Several of the respondents stated that they do not check calculations in detail; the focus is instead on ensuring that the consultant is competent enough and that the input to the calculation looks reasonable. Furthermore, if the fire service for some reason want to have detailed review of the design they can request a review by an expert certified in accordance to SAK3 [44].

In the operational area is experience from previous incidents also important. The situation and the visual cues on a fire scene are interpreted and analysed in order to make decisions. When interventions are made, effects that can be seen visually from the outside, by firefighters on the inside or with infrared cameras, are interpreted to support decisions. Calculations and quantitative judgments with regard to fire dynamics are rarely or never used during a fire incident. One interviewee gives an example when expertise was called into assess the structural capability of a building where a fire had raged for days; however, none of the respondents gave any concrete examples of quantification based on fire dynamics during this stage. A few respondents mentioned that some rule of thumb could be applied, e.g. approximate the size of a full-developed fire based on the size of the room openings in order to estimate the amount of water needed (similar to the second example given in Sect. 1.1). A couple of respondents mentioned that it is important to be able to interpret if you are dealing with a ventilation controlled or fuel controlled fire, because it affects the actions taken by the fire service. Quantitative assessments seems however to be used occasionally, when planning for operational actions at high risk facilities that for instance handles large amounts of flammables (including solids as well as liquids and gases).

It was mentioned that traditionally the focus of fire investigations are on finding the cause of the fire and ignition source. However, several of the interviewees mentioned that fire dynamics theory is used in fire investigations to get an understanding of the course of events. Qualitatively reasoning based on fire dynamics theory seems to be used often, however the interviewees also gave several examples of quantitative estimates, e.g. assessing the amount of propellant used in arson fires, radiative heat flux calculations (similar to the third example given in Sect. 1.1) and duration of fires based on oxygen consumption calculations. One of the respondents describes that estimate calculations can be matched with information from the personal that took part in the firefighting activates in order to adapt calculations.

The fire service in Sweden is often asked by the police to provide a statement (Swedish term: sakkunnigutlatande) to the court about the risk of fire spread when there is suspicion of arson or negligence. A majority of the interviewees stated that such statements are sometimes backup by qualitative and quantitative reasoning based on fire dynamics. Such reasoning is however rarely documented in detail in terms of fire dynamics theory in any official record.

\subsubsection{Potential and Need of Using Fire Dynamics Theory in Fire Service Activi-} ties The interviewees were rather unanimous that greatest potential is within fire investigations, several of the respondents pointed out that the timeframes are 
much longer in that area which means that there should be greater opportunities to do more analysis. Some of the interviewees also see possibilities to use fire dynamics more in the preventative area, e.g. to do rough estimates in support of remarks on fire safety deficiencies after inspections. When it comes to the operational work, some of the respondents said that assessments and decisions needs to be quick and based on gut feeling and experience; consequently, there is no time and no apparent need to assess the situation with the help of fire dynamics. Other respondents mentioned that there is a great need to use fire dynamics theories in complex and less frequent situations than the normal compartment fire, e.g. fires in large spaces, facades, cavities and similar. Situations where there is limited ventilation were also mentioned as such a situation. These types of fires are difficult for the fire service to handle because the experience and training as well as the theoretical knowledge are limited.

One respondent points out that compartment fires can be tackled almost with a surgical precision. Another respondent argues that compartment fires can be undertaken better than more complex situations since they are by comparison easy to handle and not much can go wrong, which results in that the fire service is often satisfied with the result. Nonetheless, both respondents agrees that the effect of an improved fire service operation would be more noticeable the rarer events, e.g. a fire in an industry or warehouse.

There is very seldom time to do any estimate calculations on the fire scene according to several respondents. However, a possibility according to one of the respondents is to have an officer devoted to doing analyses of e.g. fire dynamics and building behaviour to support tactical decisions. This is however only realistic for extensive fires in areas where the fire service has plenty of resources.

The interviewees' general opinion is that if calculations are performed within the fire service it should be estimate calculations, e.g. hand-calculations or simple computer models. Because, there is no need to provide very precise calculations and the uncertainties in inputs are large; thus, performing advanced modelling (i.e. CFD) is not an alternative for the fire service at any stage. However, a few respondents mentioned that advanced calculations sometimes are done in fire investigations by other parties, e.g. by consultants on behalf of insurance companies or by the Swedish Accident Investigation Authority, and that it could be something that the fire service will do more as a part of investigations in the future.

In a specific question the respondents were asked if they thought that the need to use fire dynamics theories had increased during the last couple of years. Here, the respondents disagreed, some pointed out that there has always been a need to use fire dynamics theories. Others believed that the need has increased and will increase even further, because more and more is required by the fire service and the building stock has become more diverse. There are different types of building materials today and they behave in different ways in fires. In addition, performance based design is more common, which means that there is a greater variety of fire safety solutions in buildings today than a couple of decades ago. 


\subsubsection{Present Status in the Education of Fire Dynamics Theory in Relation to Fire} Service Activities The interviewees were asked if they felt that something was missing in their theoretical training or if they have the knowledge needed to assess spread of fire and smoke in the tasks they face at the fire service. There are some different opinions here, but most thought that they had sufficient theoretical knowledge about fire dynamics; however, they lacked the link between theory and practice when they studied. The focus at university is on the theory and the practical examples with regard to fire service applications are missing. This means that the fire engineers at the fire service need to do this connection themselves based on the practical experiences that they get while working, which might not be an easy task for everyone.

A few respondents pointed out that they lacked theoretical understanding of fire dynamics in complex spaces and inside structural elements. One respondent said that they train and practice on the easy things and the things that they already know, with references to compartment fires and training of structural firefighting by the use of steel containers. Another respondent said that a lot had happened in terms of research during the last years. A majority of the interviewees stated that there is a need for refresher courses for fire engineers working in the fire service. Then, such courses should include fire dynamics theory with a clear link to how it can be applied in the different areas of the fire service.

The competence development with regard to fire dynamics that the respondents undergo are at the best connected to short conferences on irregular intervals. Some of the respondents mention that they perform courses at the local fire service in fire dynamics for firefighters. Such courses, with a few exceptions, are based on the knowledge that was gained by the local fire engineers during their education at the university, which means that the practical connection is, most likely, still missing. However, there are exceptions and one respondent mentioned that they have made an effort to implement new research and included practical elements in their local course for firefighters in fire and building behaviour.

\section{Discussion}

A combination of a literature review and an interview study was performed in this work. These two methods approach the problem understudy from different directions and are seen as complimentary. The literature review gave a glimpse of the research preformed in regard to the use of fire dynamics in the fire service and the interview study gave the fire service perspective.

Based on the review of the selected papers it is clear that the majority of the work performed is targeted towards operational duties of the fire service, and most of these publications deal with improving and planning of fire services operations. For instance, the use of modelling is stressed as a useful tool to estimate the effectiveness of different firefighting tactics, as it is a good complement to training and experience from the field [37]. A couple of publications dealt with fire-forecasting, which is an area that not was brought up by the interviewees. It was rather so that several claimed that there were neither time nor resource to 
make detailed calculations during firefighting operations. This, though a little contradictory, is considered to justify the use of sensors and other technical aids under the operational area as long as they do not become time consuming or depleting resources from the fire service. Such tools that are reliable and can support decision making at the fire scene would be valuable. The technology is not there yet, as described in some of the reviewed publications [31], but further research efforts and development can make it possible. An important aspect is that the operator should know how such supportive systems work and understand the underlying fire dynamics. Otherwise, the system might work as a black box and misconceptions or errors might occur. When it comes to publications dealing with preventative fire service activities only a few examples were found in the review. The reason for this might be that the area may not be a subject for extensive research, but more of an application of scientific results in engineering.

The interviewees saw the greatest benefits of quantitative fire dynamics assessments in the preventative or investigative area of fire service activities. There are several possible reasons for the discrepancy in this matter between the review study and the perception of the interviewees. It can be that the research in this field is limited or at least not reported in the type of sources that are included in the literature review. Another reason can be that fire dynamics theory has not been thought of as a valuable tool outside the operational area. The prescriptive requirements in the building codes is often a level by which an existing building can be compared too when inspections are made by the fire service; furthermore, fire investigations are often performed with a focus on the fire cause and the fire development is explained rather superficially. However, if preventative activities and the results from investigations should provide valuable information for creating safer buildings and improve the work and safety of fire service personnel, it is likely that increased use of fire dynamics theory in these areas can contribute.

As was mentioned by some of the interviewees, there may be a knowledge gap in fire dynamics theory between fire consultants and the fire service in the building design stage. However, it should be remembered that the fire service personnel, in general, have more practical experience of building fires and can review the design from a more practical angel than the consultants. So, in this regard the fire service may be able to compensate for a slightly more limited understanding of analytical fire safety design of buildings, compared to fire consultants.

Two comprehensive databases were used in the literature review and the result of the search is considered to be quite comprehensive. Even so, it is still limited and there might be publications that are not covered by the databases or that have been determined to be irrelevant in the screening, which could have added some value to the literature study. There are some publications that are considered to be relevant that did not appear in the literature review. These have been mentioned and discussed in the background section.

The interview study is performed with only Swedish participants thus the international perspective is missing meaning that the results might not be possible to directly translate to other countries. The Swedish system, where a large part of the senior fire officers holds a degree in fire safety engineering, is rather unique in the world and the problems that exists with regard to the area under study in this 
paper is believed to be relevant in other countries as well. The problem with the limited connection between fire dynamics and practice in courses and training is considered to be serious and it is a problem that is not believed to be isolated to Sweden.

The fire service is faced with compartment fires on a regular basis and knows what to expect in terms of fire dynamics and fire protections systems, such as separating walls or sprinkler systems. The fire services in Sweden are in many cases based upon, designed and organized for operating at compartment fires in teams of two firefighters equipped with breathing apparatus. This might to some extent reflect the effectiveness in combining separating walls with firefighters having some basic knowledge in fire dynamics theory. Also, it should be noted that basic firefighter training is a two-year program in Sweden, and some of the training material $[11,16,45]$ used has a clear scientific background. Furthermore, the typical fuel load, geometry and sizes of enclosures were compartment fires occurs (e.g. in apartments) is quite similar, which means that the fire behaviour also is comparable between different fires. In general, this means that procedures and rules of thumb have been developed based on experience and no special considerations in regard to fire dynamics are necessary in order to solve the situation. However, it is believed that it is not possible to base decisions on solely experience from previous events.

There should be a clear benefit of knowing fire dynamics theory at the fire service. The experience gained whilst working in the fire service is of course essential but a solid theoretical knowledge ought to make a difference. However, fire engineers working at the fire service do not use their theoretical knowledge in a quantitative manner on a regular basis, still they seem to address it frequently whilst performing qualitatively assessments. With that said there are room for improvement and the first step could be to connect theory and practice related to fire service activities to a higher degree. There are practical examples of this and, as previously mentioned, textbooks $[11-13,16]$ that do this. It is also a fact that people tend to forget if they do not use or apply their knowledge frequently, which means that refresher courses or seminars in this area should be held with regular intervals.

There are situations that the fire service face where relevant fire dynamics theory has yet not been sufficiently developed. Examples of this can be fires in large enclosures or fires in structural elements like facades or cavities. When it comes to such events, which for most fire service organizations in Sweden occurs a few times or less during a year, it is a challenge to keep the knowledge up to date and fresh. Such events are hard to practice or train for, because there is a larger diversity in how fire develops and smoke spreads in, e.g. large industries or structural elements, compared to the apartment fires. So, it is not evident how to perform a practical training session. For such events, where the practical experience is limited, the importance of theoretical understanding is much larger. If a situation has not been experienced before, the only way to estimate what is going to happen is to rely on the understanding of fundamentals, i.e. fire dynamics theory. The problem here is however that the theoretical knowledge is lacking at all levels. The focus in fire dynamics courses and textbooks is mostly on compartment fire 
dynamics, when it comes to more complex events, like fires in large enclosures and cavities, the relevant phenomena is less understood and consequently not described very extensively in any textbooks. This means that the situations where fire dynamics theory could be the most beneficial during fire service operations, is where such theory is lacking the most.

Based on the review and discussion in this paper it is believed that there are strong benefits of a solid knowledge in fire dynamics in all types of fire service activities associated with fire safety in buildings. Such knowledge can assist the fire service as well as improve the operations; it is also believed to be a prerequisite in order to evolve fire service and implementing new technical aids and concepts like smart firefighting.

\section{Conclusion}

It is believed that solid knowledge about fire dynamics is fundamental in any type of fire service activities associated with fire safety in buildings. This paper has reviewed how fire dynamics theory is used in the fire service and the potential and need to use it more in the future. The matrix presented in Table 4 gives an overview of the findings.

Fire dynamics theories are currently used more in preventative and investigative area than in the operational area. The primary reasons for this is that the timeframe in general is much shorter in the latter and that there are established procedures and tactics that works well for ordinary fire situations (especially compartment fires in residential buildings). However, the potential of using fire dynamics in all areas in the fire service (second row in Table 4) are greater than the current use. The potential is higher in preventative and investigative area than in the operational area mainly due to the greater possibilities to use fire dynamics theory given the longer time frames; however, there is a potential in the operational area and especially when it comes to events that occurs less frequent and with a longer duration than the normal compartment fire, like fires in complex buildings. This means that there is room for improvement of the use of fire dynamics in the fire service and a way forward could be a stronger link between theory and practice.

\section{Table 4}

\section{The Current Use, Potential and Need and Current Theoretical Status}

\begin{tabular}{llll}
\hline & Preventative & Operational & Investigative \\
\hline Current use & Fair & Poor & Fair \\
Potential and need & Very good & Good & Very good \\
Current theoretical status & Good & Fair & Good \\
\hline
\end{tabular}

Four levels are used in the table in order to distinguish the status of fire dynamics theory in different fire service activities 
Table 4 illustrates that more research is needed, because the possible potential is higher than the current theoretical status (second and third row in Table 4). This means that there are incentives to increase the current theoretical knowledge through further research in fire dynamics in buildings and how it can be used by the fire service.

\section{Acknowledgments}

The research presented in this paper is funded by the Swedish Civil Contingency Agency (MSB), which is gratefully acknowledged. The following organisations are also acknowledged for their will to participate in the interview study: Räddningstjänsten Skåne Nordväst, Räddningstjänsten Syd, Räddningstjänsten i Kristianstad, Swedish Civil Contingency Agency, Lund University, Räddningstjänsten StorGöteborg, Södertörns Brandförsvarsförbund.

\section{Open Access}

This article is distributed under the terms of the Creative Commons Attribution 4.0 International License (http://creativecommons.org/licenses/by/4.0/), which permits unrestricted use, distribution, and reproduction in any medium, provided you give appropriate credit to the original author(s) and the source, provide a link to the Creative Commons license, and indicate if changes were made.

\section{Appendix: General Interview Template}

The performed interviews were open, which allowed for a discussion and followup questions. All interviews were performed by the first-author. The following areas and questions were discussed in all of the interviews.

General description of the interviewee and the fire service

- How many fire engineers are employed at the fire service?

Fire dynamics theories

- How is knowledge about fire dynamics and fire development in buildings used at the fire service today?

- In what areas within the fire service (preventative, operational, investigative) is there a potential and/or need to use fire dynamics theories more?

- Has the demand to use fire dynamics theories increased during the years, in that case why?

- Are any calculation methods in regard to fire dynamics used at the fire service? 


\section{Education}

- Was there anything missing in your training/education in regard to fire dynamics and fire development?

- Do you have any internal education on fire dynamics for firefighters?

- What from your fire safety engineering training (course or skill) do you take the most benefit from in your daily work?

- Do you see any need for further training of fire engineers in the field of fire dynamics and fire development?

\section{References}

1. Swedish Constitution (1944) Brandlag [Fire Law], No 521

2. Constitution Swedish (2017) Lag om skydd mot olyckor [Act on protection against accidents]. SFS 2017:745

3. Butler B, Wang,P (2015) Chapter 9: Fire service data user applications-pre-emergency and post-event. In: Research roadmap for smart fire fighting. National Institute of Standards and Technology, USA. http://dx.doi.org/10.6028/NIST.SP.1191

4. Jenkins P (2005) Capital gain. Fire Prev Fire Eng J 65. Fire Protection Association, Institution of Fire Engineers, London, UK

5. Wang YC, Marsden J, Kelly M (2011) Challenges of fire fighting in fire engineered built environment. Proc Eng 11:583-592. https://doi.org/10.1016/j.proeng.2011.04.699

6. Pålsson CM (2006) I räddningens tjänst-Brandingenjörsutbildningen vid Lunds tekniska högskola [In the service of rescue-The fire engineer education at Lund University]. Report 7027. Department of Fire Safety Engineering, Lund University, Sweden

7. Swedish Rescue Service Agency (2004) Föreskrifter om behörighet att vara räddningsledare i kommunal räddningstjänst [Regulation on the authority to be rescue leader in the emergency services]. SRVFS 2004:9. Karlstad, Sweden

8. Madrzykowski D (2013) Fire dynamics: the science of fire fighting. Int Fire Service J Leadersh Manag 7:7-16

9. Grant C, Hamins A, Bryner N, Jones A, Koepke G (2015) Research roadmap for smart fire fighting. National Institute of Standards and Technology, USA. http://dx.do i.org/10.6028/NIST.SP.1191

10. Svensson S (2014) Byggnadstekniskt brandskydd i MSB:s utbildningar [Fire safety of buildings in the education and training provided by MSB]. Report 3182. Department of Fire Safety Engineering, Lund University, Sweden

11. Bengtsson LG (2001) Enclosure fires. Swedish Rescue Services Agency, Karlstad, Sweden. https://www.msb.se/RibData/Filer/pdf/20782.pdf. Accessed 19 Jan 2018

12. Grimwood P (2017) Euro Firefighter 2: 6,701 Building Fires. Jeremy Mills Publishing, UK

13. Walker B (2016) Fire Dynamics for Fire Fighters. Pavilion Publishing and Media, UK

14. DeCicco P, Cresci J, Correale H (1972) Fire tests, analysis and evaluation of stair pressurization and exhaust in high-rise office buildings. Polytechnic Institute Brooklyn, New York, USA

15. Svensson S (2001) Experimental study of fire ventilation during fire fighting operations. Fire Technol 37(1):69-85. https://doi.org/10.1023/A:1011653603104 
16. Svensson S (2005) Fire ventilation. Swedish Rescue Services Agency. Karlstad, Sweden. https://msb.se/RibData/Filer/pdf/20879.pdf. Accessed 19 Jan 2018

17. Karlsson B, Quintiere JG (1999) Enclosure Fire Dynamics. CRC Press, Boca Raton, USA

18. Drysdale D (2011) An Introduction to Fire Dynamics, 3rd edn. Wiley, UK

19. Barnett C (2004) Calculation methods for water flows used for fire fighting purposes. SFPE (NZ) Techcnical Publication-TP 2004/1. http://www.highrisefire.co.uk/docs/sfpeTP2004-1.pdf Accessed 9 May 2018

20. Web of Science https://webofknowledge.com. Accessed 19 Jan 2018

21. Scopus https://www.scopus.com. Accessed 19 Jan 2018

22. Boston collage libraries, scopus at boston college: scopus vs web of Science, https://libg uides.bc.edu/BC2016Scopus/Scopus_V_WebofScience. Accessed 19 Jan 2018

23. Pesic D, Mihajlovic E, Cvetanovic S (2010) Firefighters risk during sanitation of chemical accidents. In: 19th Annual international conference on Pozarni Protection, Ostrava, Czech Republic, pp 241-245

24. Hofmann A, Knaust C, Krüger S, Raspe T, Deubel J (2014) Detailed analysis of a smouldering fire scenario at the murder scene experimental and numerical investigations. Fire Mater 38(8):806-816. https://doi.org/10.1002/fam.2222

25. Kerber S (2013) Analysis of one and two-story single family home fire dynamics and the impact of firefighter horizontal ventilation. Fire Technol 49(4):857-889. https:// doi.org/10.1007/s10694-012-0294-55

26. Kerber S (2012) Analysis of changing residential fire dynamics and its implications on firefighter operational timeframes. Fire Technol 48(4):865-891. https://doi.org/10.1007/ s10694-011-0249-2

27. Grimwood P, Sanderson I (2015) The County/Metro research into firefighting suppressive capacity and the impact on building fire damage at $>5000$ UK building fires. Fire Saf J 71:238-247. https://doi.org/10.1016/j.firesaf.2014.11.027

28. Grimwood P, Sanderson I (2015) A performance based approach to defining and calculating adequate firefighting water using s.8.5 of the design guide BS PD 7974:5:2014. Fire Saf J 78:155-167. https://doi.org/10.1016/j.firesaf.2015.08.007

29. Chang $\mathrm{CH}$, Huang $\mathrm{HC}$ (2005) A water requirements estimation model for fire suppression: a study based on integrated uncertainty analysis. Fire Technol 41(1):5-24. https:// doi.org/10.1007/s10694-005-4627-5

30. Taylor A (2008) CFD - Convincing the regulator. Fire Risk Manag

31. Jahn W, Rein G, Torero J (2012) Forecasting fire dynamics using inverse computational fluid dynamics and tangent linearization. Adv Eng Softw 47(1):114-126. https:// doi.org/10.1016/j.advengsoft.2011.12.005

32. Hofmann A, Knaust C, Krüger S, Raspe T, Deubel J (2014) Assessment of development time of a smouldering fire at a crime scene experimental and numerical investigations. In: 12th international conference on fire and materials 2011, San Francisco, California USA, pp 299-308

33. Berry D (2005) Dynamic investigations. Fire Prev Fire Eng J

34. Michopoulos J, Tsompanopoulou P, Joshi A, Zhang H (2005) Towards agent-based GRID-enabled and sensor-driven fire dynamics simulation harnessed over Bluetooth and Wi-Fi devices. In: Proceedings of IDETC/CIE 2005, ASME 2005 international design engineering technical conferences \& computers and information in engineering conference, Long Beach, California, USA

35. Grimwood P (2011) High profile. Fire Risk Manag

36. Streeter D (1999) The firefighter as regulator. In: Fire and explosions: recent advances in modelling and analysis. Institution of Mechanical Engineers Seminar, London, UK 
37. Guigay G, Elíasson J, Gojkovic D, Bengtsson LG, Karlsson B (2009) The use of CFD calculations to evaluate FireFighting tactics in a possible backdraft situation. Fire Technol 45(3):287-311. https://doi.org/10.1007/s10694-008-0058-4

38. Cowlard A, Jahn W, Abecassis-Empis C, Rein G, Torero J (2010) Sensor Assisted Fire Fighting. Fire Technol 46(3):719-741. https://doi.org/10.1007/s10694-008-0069-1

39. Panindre P, Mousavi S, Kumar S (2017) Improvement of Positive Pressure Ventilation by optimizing stairwell door opening area. Fire Saf J 92:195-198. https:/doi.org/ 10.1016/j.firesaf.2017.06.007

40. Panindre P, Mousavi S, Kumar S (2017) Positive pressure ventilation for fighting winddriven high-rise fires: simulation-based analysis and optimization. Fire Saf J 87:57-64. https://doi.org/10.1016/j.firesaf.2016.11.005

41. Hsiao LK, Huang TC, Lin CY, Shen TS (2013) Simulation of bus fires in the Hsuehshan tunnel, Taiwan, using the software fire dynamics simulator. J Appl Fire Sci 23(1):43-57

42. Arinia D, Pancawardania F, Santosoa M, Sugiartoa B, Nugrohoa Y (2017) Froude modelling of fire phenomena: observation of fire-induced smoke movement in basement structure for firefighting purpose. Porc Eng 170:182-188. https://doi.org/10.1016/ j.proeng.2017.03.042

43. UL Firefighter Safety Research Institute, Research Projects-Training, https://ulfirefigh tersafety.org/research-projects/training/index.html. Accessed 19 Jan 2018

44. National Board of Housing, Building and Planning (2011) Boverkets föreskrifter och allmänna råd om certifiering av sakkunniga inom brandskydd [Regulations and general advice on certification of fire protection specialists]. BFS 2011:17-SAK 3. Karlskrona, Sweden

45. Särdqvist. S. (2002) Water and other extinguishing agents. Swedish Rescue Services Agency, Karlstad, Sweden. https://www.msb.se/RibData/Filer/pdf/23061.pdf Accessed 9 Feb 2018

Publisher's Note Springer Nature remains neutral with regard to jurisdictional claims in published maps and institutional affiliations. 